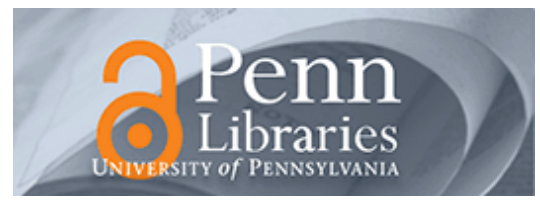

Studies in Visual Communication

Volume 6

Issue 1 Spring 1980

Article 9

1980

Psychological States and the Artist: The Problem of Michelangelo

Jane Kromm

Recommended Citation

Kromm, J. (1980). Psychological States and the Artist: The Problem of Michelangelo. 6 (1), 69-76.

Retrieved from https://repository.upenn.edu/svc/vol6/iss1/9

This paper is posted at ScholarlyCommons. https://repository.upenn.edu/svc/vol6/iss1/9

For more information, please contact repository@pobox.upenn.edu. 


\section{Psychological States and the Artist: The Problem of Michelangelo}




\title{
Psychological States and the Artist: The Problem of Michelangelo
}

\author{
Jane Kromm
}

The reality of Michelangelo's melancholia has in the past been a major consideration in the work of scholars attempting to understand the difficult personality of this great artist. Interpretations have ranged from an extreme, virtually psychotic, melancholia to a general melancholic state of mind affected to indicate creative suffering. In recent scholarship, however, judgments have become more severe. For example, Howard Hibbard $(1974: 175,179)$ maintains variously that Michelangelo was "'ultra-sensitive," '"undoubtedly neurotic,' and subject to "continual depression," in a somewhat liberal use of modern psychological terms. Such potentially diagnostic adjectives may be the modern extension of a long-established tradition aptly summarized by the Wittkowers:

There cannot be many adjectives that have not, at one time or another, been used to characterize his [Michelangelo's] personality. He has been called avaricious and generous; superhuman and puerile; modest and vain; violent, suspicious, jealous, misanthropic, extravagant, tormented, bizarre, and terrible, and this list is far from being complete. [1963:72]

This quantity of adjectives, whose range alone suggests ambivalence, if not ambiguity, raises some concerns about their effect on Michelangelo studies. Specifically, questions about the function and subsequent influence of these descriptive terms come to mind. Such usage is, it seems, primarily expressive, an author's attempt to convey some intangible aspect of the artist's work and personality. Such a function is suggested by these observations: "A tragic, a pathetic feeling is found in most of Michelangelo's works, ... (Weinberger 1967:2), and "Michelangelo's gruesomest image of rejection is a bundle of shame and despair" (Steinberg 1975a:52-53). Sometimes a serious attempt is made to assimilate Michelangelo's character to modern categories of psychology when the suggestion of psychosis is implied: "The Lives of Condivi and Vasari clearly reflect Michelangelo's paranoid hostility to Bramante" or the contention that Michelangelo's rivalry with Raphael "scarred Michelangelo for life and impaired his perception of reality" (Hibbard 1974:92, 144). And even terms borrowed from psychological dynamics are recruited in the suggestion that a "gradual catharsis characterizes the development of his personality as well as the structure of his individual works"' (de Tolnay 1960:94).

Jane Kromm is a Doctoral Candidate, Graduate Institute of Liberal Arts, Emory University, and a Lecturer in Art History, Atlanta College of Art.
As this last example suggests, characterizations of Michelangelo's personality often lead to, and sometimes replace, our critical understanding of stylistic problems and anomalies in Michelangelo's art. That this tendency is pervasive is seen both in general observations that "works . . . translate the passionate side of his temperament" and in specific instances such as the David, in which "an ambiguous, unfulfilled, emotionally tense moment in the hero's career' is said

"'to correspond to his [Michelangelo's] own mental state"' (de Tolnay 1975:2-3, Hibbard 1974:61). Or that the strangely antiheroic subject matter of the Battle of Cascina gave Michelangelo the "opportunity of projecting . . . the emotional stresses of his early existence"' (Hartt 1964:26).

Although no one would seriously hold that Michelangelo was mad, few are willing to consider his art untouched by personal conflict. Remarks about such conflict frequently accompany explanations of the discrepancies in stylistic development in Michelangelo's early works. Dissimilarities between the Battle of the Centaurs and the Madonna of the Stairs are said to correspond to "the need which the young artist felt to express in disparate works the contrary tendencies of his being: the contemplative, seeking to evoke the eternal image of beauty, and the active, seeking to incarnate the turbulent forces of his own temperament" (de Tolnay 1975:2-3). The stylistic differences between the Santo Spirito Crucifix and the San Petronio statues are similarly attributed to "various aspects of Michelangelo's unfolding personality, from an extreme grace and gentleness to an emotional violence" previously formed by Michelangelo's childhood experiences of " the rivalries of a male-dominated environment"' (Hartt 1964:20,17). Such dichotomous characteristics and their potential to result in conflict are even used to describe Michelangelo's entire artistic career as an expression of "psychic as well as overt conflict, a strong sense of frustration" (Hibbard 1974:25) so pervasive that it can even be found in Michelangelo's architectural designs in their "evocation of compression and frustration" (Ackerman 1966:17). It would seem not merely coincidental that many of the Wittkowers' adjectives take the form of antitheses. In a more critical spirit, such antitheses are not always seen as reflections of Michelangelo's personality, but rather as "metaphors of strength under constraint, of individual will overruled"' (Steinberg 1975b:37).

Even though many of the personal qualities ascribed to Michelangelo carrying the implication of serious mental disturbance to modern thinking about personality have been attributed to the topos of the melancholic artist of the Renaissance (Wittkower 1963:chaps. 4 and 5), the tendency to consider Michelangelo unstable in a modern sense continues. Moreover, it is clear that such interpretations have a tendency to become serious avenues by which the 
style and iconography of Michelangelo's oeuvre are often approached. Therefore, in an attempt to clarify the problem of Michelangelo's state of mind, this study will utilize some of Michelangelo's letters and poems, his art, and the biographies by Condivi and Vasari. ${ }^{1}$ Perhaps a clearer notion of the psychological characteristics Michelangelo demonstrated may be ascertained from these primary sources, along with a determination of whether diagnoses of severe conditions such as neurosis, constant depression, and psychosis are valid. Considering that melancholia and psychosis have not always been so closely allied in the past as they are in our century, Renaissance attitudes toward both phenomena will also be examined. A major source in this aspect of our investigation is Ariosto's Orlando Furioso, in which, as it well known, the protagonist succumbs to madness. In this way it is hoped that an understanding of Michelangelo's personality, and of the Renaissance conceptions of melancholia and madness, may be more accurately delineated.

The experiences of Michelangelo that may be construed as evidence of melancholia seem to cluster around several characteristic features. These are a sense of suffering from the harshness of existence, sadness revealed through introspective insight, grief and mourning, love, depression, and ruminative or obsessional concerns.

Suffering from the harshness of existence is a frequent theme in Michelangelo's letters. He refers to his "miserable existence" and to his living conditions as affording him "the greatest discomfort" (Ramsden 1963:vol. I, letters 33 and 37). ${ }^{2}$ Most of these complaints, however, are directed toward Michelangelo's family in circumstances in which their demands upon him appear to strain him, and are often completed by the phrase that Michelangelo suffers only to help his family. A letter of 1509 states:

For 12 years now I have gone about all over Italy, leading a miserable life; I have borne every kind of humiliation, suffered every kind of hardship, worn myself to the bone with every kind of labor, risked my very life in a thousand dangers, solely to help my family; . . . [Ramsden 1963: vol. I, letter 49$]^{3}$

followed three years later by:

For I lead a miserable existence and reck not of life nor honor-that is of this world; I live wearied by stupendous labors and beset by a thousand anxieties. And thus have I lived for some 15 years now and never an hour of happiness have I had, and all this have I done in order to help you, ... [Ramsden 1963:vol.I, letter 82] ${ }^{4}$

The theme of victimization is obvious and recurrent. To what extent these plaints induced guilt in Michelangelo's family is not ascertainable, but the somewhat manipulative and reproachful qualities of the letters are less revealing for our purposes than is Michelangelo's poetry when it treats the same subject.

That a harsh life suits Michelangelo's interpretation of life and art is expressed in the following excerpts from his poems of 1532 and 1547 , respectively:

I live on my own death; if I see right,

My life with an unhappy lot is happy;

If ignorant how to live on death and worry,

Enter into this fire, where I'm destroyed and burnt.

[Gilbert 1963:36, no. 54]

No one has mastery

Before he is at the end

Of his art and his life.

[Gilbert 1963:173, no. 323] ${ }^{6}$

Michelangelo reveals his understanding of the benefits such an existence can provide; in fact, several poems reveal not only a sense of the positive value of distress, but an ironic appreciation of the inherent paradox:

I get my happiness from my dejection,

And these disturbances give me rest;

To him who asks it, God may grant ill-fortune!

[Gilbert 1963:150, no. 265; terza rima stanzas, Girardi 267]

My honored art, wherein I was for a time In such esteem, has brought me down to this:

Poor and old, under another's thumb.

I am undone if I do not die fast!

[Gilbert 1963:151, no. 265; Girardi 267]

The harsh existence to which Michelangelo has subscribed is one of hard work and dedication, accompanied by the difficulties which such a course entails, dealing as it does with the extremes of existence. That such an interpretation of life is not without its pretensions is acknowledged by Michelangelo through his ironic self-criticism. This aspect of Michelangelo's suffering, then, appears to be self-inflicted, satisfying, and tied strongly to a sense of striving toward a higher goal. The extent to which these features comprise melancholia is certainly minimal. It is both a commonplace and long-standing feature of melancholia for introspection to lead to inaction, a view clearly untenable in this instance.

These examples point toward our next theme, the consideration of Michelangelo's insight into his own experience. In this vein, Michelangelo adds in a letter of 1515 to his father: "I do not go running after fictions and am not therefore quite crazy, as you all imagine (italics mine)" (Ramsden 1963:vol. I, letter 107). ${ }^{7}$ It is instructive that this excerpt reveals Michelangelo's own conception of madness as a failure to discern the truth; that is, a mentality immersed in delusions or illu- 
sions is what he emphasizes in this use of pazzia. And that Michelangelo does not think himself possessed of this characteristic is suggested in the following letter of 1524 :

Yet because they say they find me in some way strange and obsessed, which harms no one but myself, they presume to speak ill of me and to abuse me; which is the reward of all honest men. [Ramdsden 1963: vol. I, letter $161]^{8}$

Michelangelo understands his own difficulty as being obsessional in nature, and another letter of 1542 confirms the constancy of his point of view:

I reply that one paints with the head and not with the hands, and if one cannot concentrate, one brings disgrace upon oneself. Therefore, until my affair is settled, I can do no good work. [Ramsden 1963:vol. II, letter 227]

Moreover, this passage reveals the obsessional's concern with thought, with the products of thought, and with the preeminent position of work and accomplishment in the obsessional character's view of existence..$^{10}$

It is commonly accepted that Michelangelo's insight into his own character was remarkable, but that his understanding of this character as obsessive is rarely, if ever, emphasized. A frequently quoted letter of 1525 reveals this understanding quite emphatically:

Yesterday evening our friend Capt. Cuio and several other gentlemen kindly invited me to go and have supper with them, which gave me the greatest pleasure, as I emerged a little from my depression, or rather from my obsession. I not only enjoyed the supper, which was extremely pleasant, but also, and even more than this, the discussions which took place. [Ramsden 1963:vol. I, letter 170$]^{11}$

From the context of Michelangelo's numerous uses of pazzo, it would seem that he considered himself to be more obsessed and preoccupied with his thoughts than depressed, a state which our other excerpts support. ${ }^{12}$ Regarding thought content, however, the differential between melancholia and an obsession with melancholic or sad concerns may be difficult to ascertain. From an analysis of the letters and poems alone, it is likely that we may conclude only the coexistence of these two major characteristics, the melancholic and the obsessional. However, the biographies by Condivi and Vasari, which contain information concerning two important variables in this differential-Michelangelo's habits of daily life and his reactions to the loss of loved ones (both aspects being diagriostically significant to the melancholic and obsessional conditions) - will be considered.
In their treatment of Michelangelo's life, both Condivi and Vasari make generalized statements regarding Michelangelo's character. They explain his reputation as being eccentric and bizarre to be the result of the zeal to which he dedicated himself to art rather than some problem within his own personality. Vasari also firmly states: "Art does not permit wandering of the mind" (Vasari 1946 ed.:292). Again, the Wittkowers, in Born under Saturn, confirm that much artistic bizarrie in this period may be ascribed to a selfconscious eccentricity to which nearly all Renaissance artists conformed, rather than to personality disorders (Wittkower 1963:chaps. 4 and 5).

Vasari and Condivi deal with Michelangelo's habits of daily living -in particular, his eating and sleeping habits. Although differing somewhat in their explanations, both relate that Michelangelo slept and ate little. Condivi attributes this to considerations of health, whereas for Vasari it is the necessary sacrifice in the life of the hard-working artist. In addition, Vasari emphasizes that much which would now be considered a sign of depression-lack of appetite and sleep disturbance-occurred when Michelangelo was still a young man and that these behaviors were largely the result of adolescent attitudes:

He has told me that, in his youth, he often slept in his clothes, so tired that it did not seem worthwhile to undress only to dress again the next morning. [Vasari 1946 ed.:294]

If not due entirely to the carelessness of youth, Michelangelo's personal carelessness and his sleeping and eating difficulties cannot soundly be ascribed to depression: an important feature in the depressive constellation, that of an inability to work, is absent. Further, the vital element in melancholia or depression - inaction - is nowhere mentioned in any account of Michelangelo's life. Such inactivity may also be found in an obsessional neurosis in "an ever-increasing degree of indecision, loss of energy, and restriction of freedom" (Freud 1963 ed.:260)-qualities similarly lacking in accounts of Michelangelo's life.

A further area of inquiry pertinent to this study is $\mathrm{Mi}-$ chelangelo's reactions to the deaths of those to whom he was close. Condivi relates, after the death of Lorenzo de' Medici in 1492:

Michelangelo returned to his father's house, and he suffered such anquish over this death that for many days he was unable to do anything. But then he became himself again and . . . carved a Hercules. [Condivi 1976 ed.:12]

Recording Michelangelo's reaction to the death of Vittoria Colonna in 1547, Condivi reveals a somewhat more serious reaction: "On account of her death he remained a long time in despair and as out of his mind"' (Condivi 1976 ed.:103). However, an excerpt 
from a letter of the same year indicates that, although quite disturbed over Vittoria Colonna's death, Michelangelo knew how to deal with it: "You'll say rightly that I'm old and distracted, but I assure you that only distractions prevent one from being beside oneself with grief'" (Ramsden 1963:vol. II, letter 281). ${ }^{13}$ Michelangelo's reaction to the death of his servant, Urbino, in 1555 , similarly does not reveal a melancholic reaction:

Urbino passed from this life to my intense grief, leaving me so stricken and troubled that it would have been more easeful to die with him, because of the love I bore him, which he merited no less; . . . [Ramsden 1963: vol. II, letter 408$]^{14}$

And, on the death of his father in the early 1530 s, a willingness to grieve and to learn from such an experience is further demonstrated:

\section{As you depart; so I must separate}

Between the son dying first and you, thereafter,

Of whom I'm speaking, tongue, pen, and lament.

By having died my dying you will teach,

Dear father, and I see you in my thought

Where the world hardly ever lets us reach.

[Gilbert 1963:61, no. 84; Girardi no. 86]

From these few excerpts, it is not unreasonable to conclude that Michelangelo's reactions to these deaths constitute normal grief reactions rather than the more protracted reaction of melancholia. Moreover, the ability to experience grief militates further against the development of depression and melancholia (Freud 1957 ed.:126-127).

In his paper "Mourning and Melancholia," Freud defines melancholia, distinguishing it from the just as intense, but more transient, experience of grief:

The distinguishing mental features of melancholia are a profound dejection, abrogation of interest in the outside world, loss of the capacity to love, inhibition of all activity, and a lowering of the self-regarding feelings to a degree that finds utterance in self-reproaches and self-revilings, and culminates in a delusional expectation of punishment. [Freud 1957 ed.: 125]

Freud states that grief shares with depression all these characteristics except for the dramatic loss in self-esteem: "In grief the world becomes poor and empty; in melancholia it is the ego itself [which becomes poor and empty]" (Freud 1957 ed.:127). Further, the mourner is conscious of who it is that has been lost; in melancholia, however, although the sufferer may be aware of whom he has lost, he may not be conscious of "what it is he has lost in them" (Freud 1957 ed.:127). The clinical picture of this disorder "is completed by sleeplessness and refusal of nourishment" (Freud 1957 ed.:128). We have remarked elsewhere that the extremity of this condition eliminates its feasibility as an interpretation of Michelangelo's character.
In sum, selections from the poetry and letters reveal not only that Michelangelo most likely experienced grief reactions within the normal range but, more importantly, that he invested much insight into the artistic expression of the dynamics (love-death, fusion-separation) of this sort of experience. ${ }^{15}$ Although clearly not suffering from melancholia or reactive depression subsequent to the loss of significant relationships, Michelangelo had an investment in situating his artistic problems within this psychological arena, suggesting that this activity as well may function as an antidepressant in much the same way as the ability to experience grief. In addition to being adaptive strengths, the former may be evidence of the obsessive character's defense of intellectual control (Salzman 1968:11). In a poem written at his father's death, Michelangelo admits that he has had a struggle between intellectual control and depression:

And even though the soul consents to reason, It does so stiffly, that I'm filled

Far more with more depression later on.

[Gilbert 1963:62, no. 84; Girardi no. 86]

Although Michelangelo is not demonstrably melancholic by modern standards, it is necessary to consider also the distinctive elements of the Renaissance conception of melancholia. The melancholic character, originally one of the four humors and aligned over the years with the planet Saturn, altered in meaning during the late Middle Ages and Renaissance. In postmedieval poetry, melancholy became associated less with medical usage and increasingly with an emphasis on a subjective and transitory mood (Panofsky et al. 1964:218). By the beginning of the Renaissance, this transitory nature was allied with a brooding withdrawal from reality. The heightened self-awareness that such a condition implied was tinged with the romantic connotation afforded a tragic hero. Moreover, melancholia came to be seen as an attractive condition:

This consciousness became so much a part of selfawareness that there was scarcely a man of distinction who was not either genuinely melancholic or at least considered as such by himself and others. [Panofsky et al. 1964:232]

It is within this perspective that the melancholia ascribed to both Michelangelo and Raphael, as well as to others in the Renaissance, must be viewed. As the Wittkowers conclude:

In the late fifteenth century a new type of artist emerged with distinct traits of personality. The approach of these artists to their work is characterized by furious activity alternating with creative pauses; their psychological make-up by agonized introspection; their temperament by a tendency to melancholy; and their social behavior by a craving for solitude and by eccentricities of an endless variety. [Wittkower 1963:91] 
The amalgamation of melancholy with artistic achievement is not restricted to artists alone, and this notion is revived in the Renaissance's resuscitation of the "Aristotelian" Problem XXX, in which all men of achievement are noted to be melancholic. The accomplishment of this revival is established in the work of the Neoplatonists, particularly Pico della Mirandola and Marsilio Ficino. Whereas Pico's emphasis is in positioning the melancholic temperament on a narrow pivotal point between divinity and animality, Ficino's emphasis is "to identify what 'Aristotle' had called the melancholy of intellectually outstanding men with Plato's 'divine frenzy' "' (Panofsky et al 1964:259). Ficino states in his monograph De vita triplici, which is devoted to this subject, that

Saturn seldom denotes ordinary characters and destinies, but rather men who are set apart from the others, divine or animal, . . . [Panofsky et al. 1964:253]

However, Ficino considers the melancholic temperament an unhappy fate, and the rest of his monograph is devoted to suggesting methods of coping with it. Ficino therefore maintains the antithesis, which melancholy has come to imply even in the face of its glorification in the role of creativity. In this way it would seem that

the many-sidedness of Saturn shrinks to a clear antithesis between extreme intellectual disorder and extreme intellectual ability, emphasizing strongly the significance and vulnerability of the latter. [Panofsky et al., 1964:252]

Thus we arrive at a point where melancholy, with its antithetical potential, can be and is affected by creative men of all sorts in the Renaissance, even in the face of its more serious onus, the threat of madness. The question to which we address ourselves now, therefore, is to what extent did the creatively melancholic man court madness and by what other forms was madness recognized in the Renaissance. Michel Foucault, in Madness and Civilization, makes note of a Renaissance literary form which acknowledges madness as the result of desperate passion:

Love disappointed in its excess, and especially love deceived by the fatality of death, has no other recourse but madness. As long as there was an object, mad love was more love than madness; left to itself, it pursues itself in the void of delirium. [Foucault 1965:30]

Foucault is specifically referring to Shakespeare and Cervantes, but it is observed in the World History of Psychiatry (Howells 1975:54) that the Italian prototype of this literary form is Ariosto's poem Orlando Furioso, published in 1516, in which Orlando is driven mad by unrequited love. Having come upon certain evidence that his loved one belongs to another, what had pre- viously been an obsession with Orlando begins to grow to delusive proportions:

A victim now of passion unreturned,

For God and king no longer he's concerned.

[Ariosto 1975 ed.:ix.1. 286.]

This withdrawal continues:

By means of notions so improbable,

And from the truth departing more and more,

Although for comfort he has little scope,

The unhappy Count contrives to build false hope.

[Ariosto 1975 ed.:xxiii. 104. 719.]

Three times, four times, six times, he read the script, Attempting still, unhappy wretch!, in vain,

(For the true meaning he would not accept)

To change the sense of what was clear and plain.

[Ariosto 1975 ed.:xxiii. iii.720.]

The role of delusions in the Renaissance conception of madness is emphasized by Foucault, particularly in its typically humanistic orientation:

There is no madness but that which is in every man, since it is man who constitutes madness in the attachment he bears for himself and by the illusions he entertains. [1965:26]

Further, as we see happening to Orlando, "In this delusive attachment to himself, man generates his madness like a mirage"' (Foucault 1965:27). However, this experience of madness is not entirely related to an intelligence which is human, or, in other words, by a disorder in thought processes. Foucault emphasizes the element of animality in the Renaissance experience of madness:

But at the beginning of the Renaissance, the relations with animality are reversed; the beast is set free; it escapes the world of legend and moral illustration to acquire a fantastic nature of its own. And by an astonishing reversal, it is now the animal that will stalk man, capture him, and reveal to him his own truth. [1965:21]

This animality is the next stage in Orlando's madness:

His grief so swells, his sorrows so amass

That madness clouds him, in which long he erred.

On the fourth-day, by fury roused once more,

The mail and armour from his back he tore.

His scattered arms mute testimony bear To his unhinged and catastrophic mood. Then next his clothing he begins to tear,

... ; unarmed his strength immense is, Barehanded, he uproots at the first blow $A$ tall and noble pine and lays it low.

[Ariosto 1975 ed.:xxxiii. 132-134. 726.] 
In this way Orlando's madness is given over to rage, fury, and the destruction of nature. This mistreatment is not confined to nature alone, however: Orlando has already abused his horse, an apparently criminal act in the Renaissance (Ariosto $1975 \mathrm{ed}: \mathrm{xxv}$ ).

In conclusion, revealing his familiarity with the Renaissance notion of the potential for madness in the very occurrence of passion (Foucault 1965:88), Ariosto speaks at the end of his poem:

For what is love but madness after all, As every wise man in the wide world knows?

Though it is true not everyone may fall Into Orlando's state, his frenzy shows What perils lurk; what sign is there more plain Than self-destruction, of a mind insane?

[Ariosto 1975 ed.: xxix]

Thus animality, rage, delusion, and self-destruction are the qualities by which Ariosto describes the experience of the madness of Orlando. Melancholic attributes, such as brooding, grief, contemplation, and inaction, are not included in the delineation of Orlando's sorry state, except for one brief stage in his decline:

The Count requests a bed but will not eat Sated with grief, he wants no other meat. [Ariosto 1975 ed.: xxxiii. 116. 722 .]

Besides this one reference, it is apparent that Ariosto does not utilize the qualities of the melancholic temperament to describe the madness of Orlando, although it is probable that Ariosto knew of them. It would seem, then, that although recognizing the potential for madness in the melancholic temperament, the Renaissance preserved something of a distinction between melancholia and madness. The attributes of melancholy were originally conceived in the distinction of various characters. If Orlando typifies the conception of madness in the Renaissance, then this confirms melancholy's association with character structure as opposed to madness. Further, given Michelangelo's own inclination to consider himself beset with obsessions, it would seem that many of the characteristics which the Renaissance attributed to melancholy are more properly ascribed to the obsessional character, or a character structure in which most defenses are of the obsessive variety. Interestingly, Orlando's cure is effected through regaining his obsessive defenseshis reintegration is established through the learning of classical balance, proportion, and control. ${ }^{16}$

This distinction between melancholia and madness is further upheld by the qualitative difference between contemporary accounts of the melancholia of Raphael and Michelangelo and those of more seriously disturbed artists such as Hugo van der Goes and Annibale Carracci (Wittkower 1963:chap. 5). In accounts of the conditions of the latter two, the inability to work assumes a primary importance. This inability to work, although a primary characteristic of melancholia, is notable in its absence from the constellation of attributes to which melancholic creative men subscribed in the Renaissance.

Although mindful of the potential for madness in the melancholic character, the Renaissance did not really confound these characteristics with psychosis or neurosis. The results of this analysis would indicate that much of the melancholy constellation may be more properly understood as constituting an obsessional character structure. That this is true for Michelangelo may be seen by observing that, despite being worried and beset by troubles, Michelangelo's ability to sustain long periods of concentration and work was never impaired, precluding an interpretation of psychosis; and there is no recorded onset of any such symptomology, about which Michelangelo would certainly have complained. Although Michelangelo dwelt on gloomy issues, his thinking, though characteristically ruminative and obsessive, never approaches the extremity of a withdrawal from reality. Further, Michelangelo's erratic behavior in social situations is not that commonly found in neurosis, conforming instead to the pattern characteristic of problems in character structure; that is, the ways in which social intercourse is mismanaged are reliable, repetitive, stable, and restricted only to specified situations. That this character structure may best be described as obsessional in nature is confirmed by the recurrence of such features as control through intellect, omniscience, and other obsessive traits.

Finally, alongside the previously mentioned distinction between melancholy and madness in the Renaissance, it seems reasonable to maintain that Michelangelo's obsessive character is also quite distinct from the Renaissance conception of madness as well as our own; certainly, little evidence has been found to justify the continuing use of severe diagnoses of Michelangelo's personality. Moreover, the tendency to project the qualities of serious conditions on Michelangelo's art has complicated the art historical assessment of his work. In addition to the interpretations cited at the beginning of this paper, the tenacity as well as the potential confusion of such psychological interpretations may be demonstrated by an instance in which the same work of art is claimed to exemplify diametrically opposite personality attributes-emotional violence and emotional detachment. In his discussion of the style of the Rachel and Leah statues, Weinberger (1967:279) concludes that "what Burckhardt regarded as an indication of coldness is rather a sign of that detachment which marks the works of Michelangelo's old age," in answer to Hartt's observation (1968:272) that "below this austere surface still pulsates the physical and emotional violence of Michelangelo's own nature.' 
The paramount importance of this interpretative bias for Michelangelo studies is heightened by Leo Steinberg's recent revisionist interpretations of Michelangelo's last paintings. While reestablishing the primacy of the visual image, Steinberg is led to question this tendency to ascribe what is unclear about Michelangelo's art to his personality, and in so doing he arrives at a new understanding of the artist's creative procedures. In his introductory discussion in Michelangelo's Last Paintings, Steinberg mentions an unusual document - the artist's list of three menus with accompanying illustrations, which begin in a neat and orderly way but eventually cascade down the right side and bottom of the paper. First published by de Tolnay, this peculiar document was once again attributed to that so-called unreliable aspect of Michelangelo's personality as another instance of the artist's being "carried away by his temperament, ...." (Steinberg 1975b:7). Not satisfied with this interpretation, Steinberg goes on to remind us that "a temperament is complex" and, after further investigation, isolates what he believes to be an important aspect of Michelangelo's working method and creative process - the impulse to construct the broadest referential framework, as the artistic "concept expands against the retentive force of some outer limit contracting upon it.' Rather than speculating on the vagaries of temperament, Steinberg attempts to elucidate the rational, structural attributes upon which Michelangelo's working process is grounded, and in so doing extends our understanding of the tendency often observed in the artist's work, and sometimes designated as his preference for obstacles, which "apparently he liked .... perhaps even sought ... out; ..." (Ackerman 1966:20). Clearly, Steinberg has arrived at a theoretically more productive conclusion than that previously suggested by Frederick Hartt. In attempting to fathom Michelangelo's preference for the exceptionally emphatic frame in his discussion of the Medici Chapel and the Tomb of Julius II, Hartt (1968:19) relied on a psychological, and distinctly negative, explanation that the frames gain prominence as part of Michelangelo's "obsessive delight in ornamentation." It is this kind of interpretation that militates against the possibility that obsessive traits such as control and omniscience may, in fact, be put to constructive use in the service of $\mathrm{Mi}$ chelangelo's artistic conceptions.

Even more revealing is Steinberg's interpretation of the Last Judgment, in which supposed pessimism, punishment, and masochism are first routed by a reexamination of the work itself and then clarified by an understanding of the artist's religious, though probably heretical, beliefs. Although the tradition of viewing the Last Judgment as a Dies Irae conforms both to scripture and primary sources, and has prompted "the ready agreement of most later writers on Michelangelo, who persist in seeing the fresco as a 'wholly punitive manifestation,' "' Steinberg has found evidence to the contrary, thereby revising the widespread and long-standing tradition of confounding Michelangelo's iconographic and stylistic intentions with negative personality traits (1975a:50). The Last Judgment can no longer be seen as the result of "Michelangelo's conceptions of ancient myths of punishment" (de Tolnay 1960:25), nor can the self-image with flayed skin be thoroughly understood as "the artist's inner nature, corroded by self-pity so intense as to become an affliction" (Hartt 1964:144). Even less is the Last Judgment yet another instance of a tendency in the artist's late years of a "recurrent masochistic attitude" (Hartt 1964-156).

Formulated on a reassessment of the structure and imagery of the Last Judgment, accompanied by documentation and interpretative support-and, significantly, by not telescoping the religious guilt of Michelangelo's beliefs into personal and neurotic guiltSteinberg can approach the optimism of a Last Judgment conceived as merciful. And this despite the fact that

for 400 years, those who gave account of the picture in word or image obeyed a compulsion to accentuate whatever seemed harsh, to unsee and suppress any tremor of exultation or gentleness. The abundance of Michelangelo's hope was either ignored or turned into its opposite. [Steinberg 1975a:60]

Perhaps the uncritical use by most Michelangelo scholars of psychological terminology which prompted this study has some justification as an expressive device. Unfortunately, however, the willingness to conflate neurotic and even psychotic traits with artistic activity, which then encroach upon stylistic and iconographic interpretations, creates a false impression of the creative person and his art-an impression that is clearly inadequate for an understanding of so major an artistic innovator as Michelangelo.

\section{Acknowledgments}

The author wishes to thank Dr. John Howett, Emory University, and Dr. Leo Steinberg, University of Pennsylvania, for their assistance and encouragement.

\section{Notes}

The present study is not concerned with examining this material in order to deduce unconscious sources of motivation or conflict as would be appropriate to a traditional psychoanalytic study of personality; see Condiv (1976 ed.) and Vasari (1946 ed.). For a recent contribution in this vein, see Panofsky et al. (1964).

2 See Giovanni Poggi, II Carteggio di Michelangelo. I:51, letter XXXVI: "un chativo essere" ; I:55, letter XL: "grandissimo disagio." 
3 See Poggi, I:96, letter LXVII: “. . . e questo e che io son ito da dodici anni in qua tapinando per tucta Italia, sopportato ogni vergognia, patito ogni stento, lacerato il corpo mio in ongni faticha, messa la vita propria a mille pericoli solo per aiutar la chasa mia;

4 See Poggi I:141, letter CVII: ". . . , che vivo meschinamente e non curo né della vita né dello onore, cioè del mondo, e vivo chon grandissime fatiche e chon mille sospecti. E già sono stato cosi circha di quindici anni, che mai ebbi un'ora di bene, e.ctucto $d$ facto per aiutarvi,

5 Gilbert's translations (1963) are used throughout, along with Girardi numbers (1967) whenever possible.

6 Fragments of lost madrigals, Girardi, App. 35. Quoted in Varchi's lecture of 1547

7 See Poggi, I: 177 , letter CXXXVIII: "Io non vo drieto a favole e non son però pazzo afacto chome voi credete;

8 See Poggi, III:27, letter DCVIII: “. . . poi, sopra qualche mia bizzarria o pazzia che e'dichon che io $\partial$, che non nuoce se non a.mme, si son fondati a dir male di me e a vituperarmi, che è el premio di tucti gl'uomini da bene."

9 See Gaetano Milanesi, Le Lettere di Michelangelo Buonarroti, letter CDXXXV: "Io rispondo, che si dipinge col ciervello et non con le mani; et chi non può avere il ciervello seco, si vitupera: però fin che la cosa mia non si acconcia, non fo cosa buona. "

10 See Leon Salzman (1968) and Sigmund Freud (1963).

11 See Poggi, III:156, letter DCCIV: ". . . . iersera el vostro amicho chapitano Chuio e certi altri gentilomini volsono, lor gratia, che io andassi a.ccena chon loro, di che ebi grandissimo piacere, perché usci' um pocho del mio malinchonicho, o vero del mio pazzo

12 The Wittkowers point out that in the sixteenth century "pazzia" could vary in meaning from madness to strangeness and eccentricity (chap. $5)$.

13 See Milanesi, letter CDLXV: "Voi direte bene che io sia vecchio e pazo: e io vi dico, che per istar sano e con manco passione, non ci trovo meglio che la pazzia."

14 See Milanese, letter CCLXXXIV: " . . . passò di questa vita Francesco detto Urbino, ${ }^{1}$ con grandissimo mio affanno; e àmmi lasciato molto af litto e tribolato, tanto che mi sare' stato più dolce il morir con esso seco, per l'amore che io gli portavo: e non ne meritava manco;

15 For a thorough discussion of important themes in Michelangelo's poetry, see Robert J. Clements (1965). Concerning the grief reaction, a recent paper of Liebert (1977) attempts to link Michelangelo's destruction of the Florence Pieta with the dynamics of ambivalence and the death of Urbino.

16 It is important to recall that this aspect of Orlando's return to sanity is accompanied by magical as well as religious themes. For example, Astolfo must travel to the moon (demonstrating the lunar-lunacy association) with St. John and retrieve Orlando's brains, which are contained there in a vial. In this way magical and religious elements are retained in addition to the more pragmatic and obsessive characteristics mentioned above.

\section{References}

- Ackerman, James

1966 The Architecture of Michelangelo. New York: Viking Press.

- Ariosto, Ludovico

1974 Orlando Furioso. Guido Waldman (trans.). New York: Oxford University Press.

1975 Orlando Furioso. Barbara Reynolds (trans.). Part I. Baltimore: Penguin Books.

- Clements, Robert J.

1961 Michelangelo's Theory of Art. New York: New York University Press.

1965 The Poetry of Michelangelo. New York: New York University Press.

- Condivi, Ascanio

1976 The Life of Michelangelo. H. Wohl (ed.). A. Wohl (trans.). Baton Rouge: Louisiana State University Press.
- de Tolnay, Charles

1960 Michelangelo. Vol. 5: The Final Period. Princeton: Princeton University Press.

1964 The Art and Thought of Michelangelo. New York: Pantheon.

1975 Michelangelo: Sculptor, Painter, Architect. Princeton: Princeton University Press.

- Foucault, Michel

1965 Madness and Civilization: A History of Insanity in the Age of Reason. New York: Random House.

- Freud, Sigmund

1957 A General Selection from the Works of Sigmund Freud. John Rickman (ed.). New York: Liveright.

1963 Complete Psychological Works of Sigmund Freud. Lecture XVII, Vol. XVI. London: Hogarth Press and Institute of Psychoanalysis.

- Gilbert, Creighton (trans.)

1963 Complete Poems and Selected Letters of Michelangelo. Robert N. Linscott (ed.). New York: Vintage.

- Girardi, Enzo N. (ed.)

1967 Michelangelo Buonarroti, Rime. Bari, Italy: Laterza.

- Hartt, Frederick

1964 Michelangelo. New York: Abrams.

1968 Michelangelo: The Complete Sculpture. New York: Abrams.

- Hibbard, Howard

1974 Michelangelo. New York: Harper and Row.

- Howells, John (ed.)

1975 World History of Psychiatry. New York: Brunner/Mazel.

- Liebert, Robert S.

1977 Michelangelo's Mutilation of the Florence Pieta: A Psychoanalytic Inquiry. Art Bulletin LIX(1):47-54.

- Milanesi, Gaetano

1875 Le Lettere di Michelangelo Buonarroti. Firenze, Italy: Ricordi Editore

- Panofsky, Erwin

1969 Studies in Iconology: Humanistic Themes in the Art of the Renaissance. New York: Harper and Row.

, Raymond Klibansky, and Fritz Saxl

1964 Saturn and Melancholy: Studies in the History of Natural Philosophy, Religion and Art. London: Nelson and Sons.

- Poggi, Giovanni

1965 II Carteggio di Michelangelo. 2 vols. Firenze, Italy: Sansoni Editore.

- Ramsden, E. H. (ed.)

1963 The Letters of Michelangelo. 2 vols. Stanford, CA: Stanford University Press

- Salzman, Leon

1968 The Obsessive Personality: Origins, Dynamics, and Therapy. New York: Science House.

- Steinberg, Leo

1975 a Michelangelo's "Last Judgment" as Merciful Heresy. Art in America (63):49-63.

1975b Michelangelo's Last Paintings. New York: Oxford University Press.

- Tusiani, Joseph (trans.)

1960 The Complete Poems of Michelangelo. New York: Noonday Press.

- Vasari, Giorgio

1946 Lives of the Artists. Barbara Burroughs (ed.). New York: Simon and Schuster.

- Weinberger, Martin

1967 Michelangelo the Sculptor. New York: Columbia University Press.

- Wittkower, Rudolf and Margot

1963 Born under Saturn: The Character and Conduct of Artists. New York: Norton.

- Zilboorg, Gregory

1941 A History of Medical Psychology. New York: Norton. 